\title{
DECONTAMINATION AND DECOMMISSIONING OF THE EBR-1 COMPLEX TOPICAL REPORT NO. 1 REMOVAL OF NaK FROM EBR-1 STORAGE PIT
}

J. C. COMMANDER

\section{Aerojet nuclear Company}

NATIONAL REACTOR TESTING STATION Idaho Falls, Idaho - 83401

\section{MASTER}

DATE PUBLISHED JUNE 1974 PREPARED FOR THE

U. S. ATOMIC ENERGY COMMISSION

IDAHO OPERATIONS OFFICE UNDER CONTRACT AT(10-1)-1375 


\section{DISCLAIMER}

This report was prepared as an account of work sponsored by an agency of the United States Government. Neither the United States Government nor any agency Thereof, nor any of their employees, makes any warranty, express or implied, or assumes any legal liability or responsibility for the accuracy, completeness, or usefulness of any information, apparatus, product, or process disclosed, or represents that its use would not infringe privately owned rights. Reference herein to any specific commercial product, process, or service by trade name, trademark, manufacturer, or otherwise does not necessarily constitute or imply its endorsement, recommendation, or favoring by the United States Government or any agency thereof. The views and opinions of authors expressed herein do not necessarily state or reflect those of the United States Government or any agency thereof. 


\section{DISCLAIMER}

Portions of this document may be illegible in electronic image products. Images are produced from the best available original document. 


\section{DISCLAIMER}

This report was prepared as an account of work sponsored by an agency of the United States Government. Neither the United States Government nor any agency Thereof, nor any of their employees, makes any warranty, express or implied, or assumes any legal liability or responsibility for the accuracy, completeness, or usefulness of any information, apparatus, product, or process disclosed, or represents that its use would not infringe privately owned rights. Reference herein to any specific commercial product, process, or service by trade name, trademark, manufacturer, or otherwise does not necessarily constitute or imply its endorsement, recommendation, or favoring by the United States Government or any agency thereof. The views and opinions of authors expressed herein do not necessarily state or reflect those of the United States Government or any agency thereof. 


\section{DISCLAIMER}

Portions of this document may be illegible in electronic image products. Images are produced from the best available original document. 


$$
\begin{gathered}
\text { Printed in the United States of America } \\
\text { Available from } \\
\text { National Technical Information Service } \\
\text { U. S. Department of Commerce } \\
5285 \text { Port Royal Road } \\
\text { Springfield, Virginia 22.151 } \\
\text { Price: Printed Copy \$4.00; Microfiche } \$ 0.95
\end{gathered}
$$

This report was prepared as an account of work sponsored by the United States Government. Neither the United States nor the United States Atomic Energy Commission, nor any of their employees, nor any of their contractors. subcontractors, or their employees, makes any warranty, express or implied, or assumes any legal liability or responsibility for the accuracy, completeness or usefulness of any information, apparatus, product or process disclosed, or represents that its use would not infringe privately owned rights. 


\title{
DECONTAMINATION AND DECOMMISSIONING OF THE EBR-I COMPLEX
}

TOPICAL REPORT NO. 1

\section{REMOVAL OF NaK FROM EBR-I STORAGE PIT}

\author{
J. C. Commander
}

Aerojet Nuclear Company

National Reactor Testing Station

Idaho Falls, Idaho 83401

Date Published June 1974

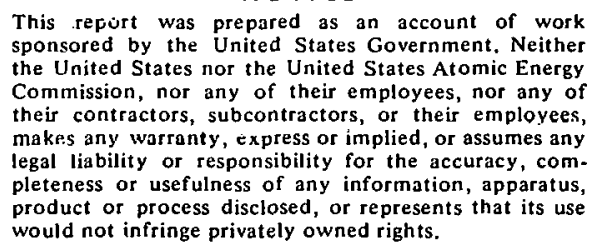

Prepared for

U. S. ATOMIC ENERGY COMMISSION

IDAHO OPERATIONS OFFICE

UNDER CONTRACT NO. AT(10-1)-1375 


\section{ACKNOWLEDGMENTS}

The author thanks E. W. Kendall and R. C. Green who were responsible for the supervision and the safety aspects of this activity. The work described was performed under the auspices of the U. S. Atomic Energy Commission. 


\begin{abstract}
This report concerns planning, preparation and operations associated with the removal of radioactively contaminated containers of sodium-potassium eutectic alloy (NaK) from the First Experimental Breeder Reactor (EBR-I) NaK storage pit, transportation of the waste material across the National Reactor Testing Station (NRTS), and restorage of waste material at the Army Re-Entry Vchicle Facility Site (ARVFS) Bunker. The activity was performed as part of the Decontamination and Decommissioning (D\&D) of EBR-I and was funded by $189 \mathrm{c} \mathrm{I}-215$.
\end{abstract}




\section{SUMMARY}

Radioactively contaminated waste from the First Experimental Breeder Reactor (EBR-I) Mark II core meltdown has been stored at the EBR-I storage pit since 1955. The objective of this activity was to remove the waste material from the storage pit to another temporary storage area. Prior to performance of this work it was necessary to conduct a radiation survey, perform a radiation and chemical hazards evaluation, select alternative storage, develop an operating procedure, and fabricate special handling tools.

The radiation survey indicated activity levels of $200 \mathrm{mR} / \mathrm{hr}$ at the top of the sodium-potassium eutectic alloy $(\mathrm{NaK})$ storage pit, and levels at contact with the waste packages ranging from $500 \mathrm{mR} / \mathrm{hr}$ to $7 \mathrm{R} / \mathrm{hr}$.

The radiation hazards evaluation establishcd the shielding requirements and the necessity for remote handling tools for removal of the waste packages from the pit. In addition, it was established that no criticality accidents could occur as a result of rearranging the waste packages.

The chemical hazards evaluation provided assurance that the work of moving the waste packages could be accomplished without risk of explosion due to the reaction of the $\mathrm{NaK}$ with potassium superoxide $\left(\mathrm{KO}_{2}\right)$.

A survey of excessed National Reactor Testing Station (NRTS) facilities was performed which resulted in the selection of the Army Re-Entry Vehicle Facility Site (ARVFS) bunker for temporary storage of the radioactively contaninated wastc packages.

$\mathrm{NaK}$ removal, transportation and restorage procedures were developed and approved by AEC-ID. The procedure and all required equipment and handling tools were checked out during a rehearsal conducted prior to the scheduled work of NaK removal from EBR-I.

The radiuactively contaminated packages of $\mathrm{NaK}$ were removed from the EBR-I storage pit on April 4, 1974 and transported across the NRTS to the ARVFS bunker where they were placed in temporary storage, secure from public access. All actions associated with this activity were conducted safely and with no incidents. 


\section{CONTENTS}

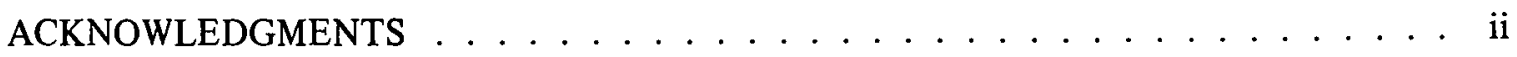

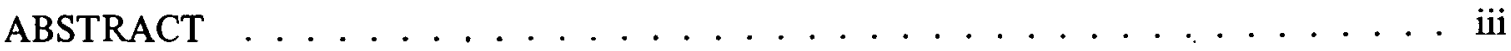

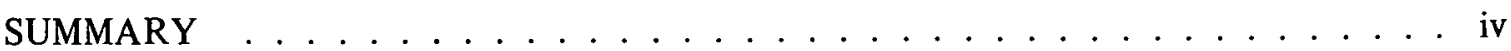

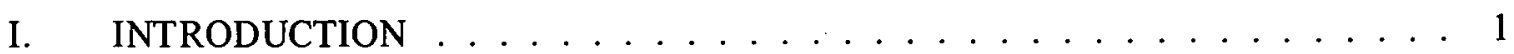

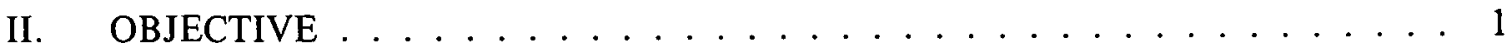

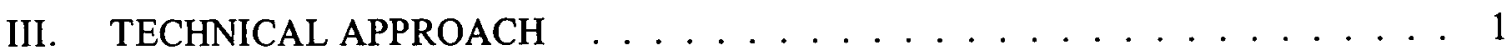

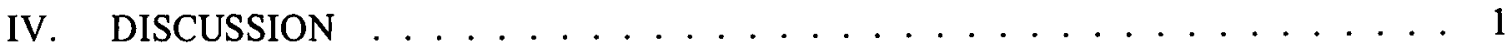

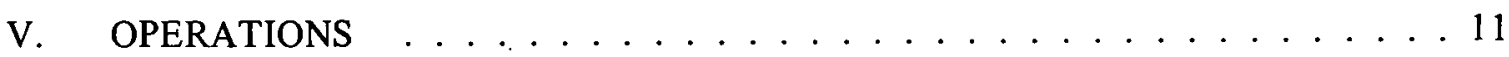

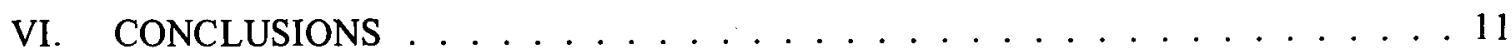

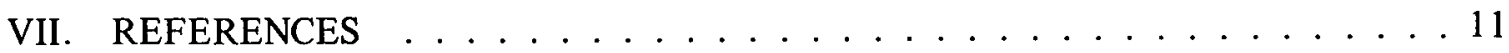

FIGURES

1. EBR-I NaK Storage Pit . . . . . . . . . . . . . . . 2

.2. NaK Storage Pit Radiation Survey . . . . . . . . . . . . . . . . . 5

3. Army Re-Entry Vehicle Facility Site (ARVFS) Bunker . . . . . . . . . . . . 6

4. NaK Drum Transfer Operation . . . . . . . . . . . . . . . 8

5. Steel Box Container in ARVFS ... . . . . . . . . . . . . 12

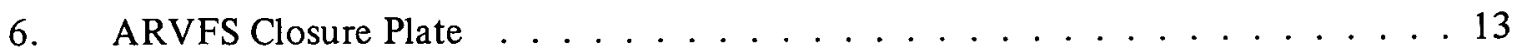

TABLE

I. Isotopic Curie Values Calculated to be Present in

Contaminated NaK Packages . . . . . . . . . . . . . . . . . 3 


\section{THIS PAGE \\ WAS INTENTIONALLY \\ LEFT BLANK}




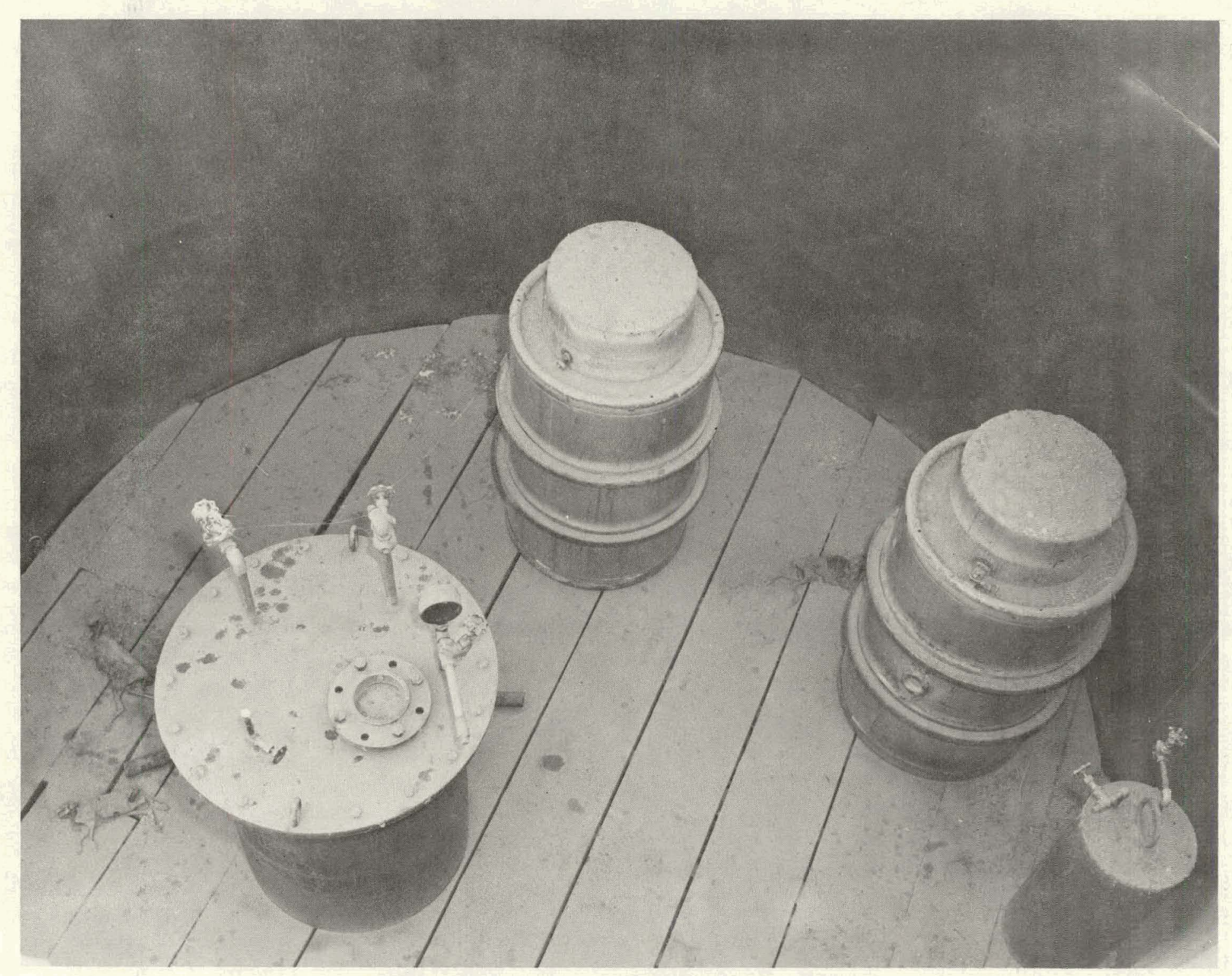

Fig. 1. EBR-I NaK Storage Pit. 
I. INTRODUCTION. The NaK storage pit is located approximately $100 \mathrm{ft}$ west of EBR-601. It was designed to provide interim storage of radioactive contaminated $\mathrm{NaK}$ coolant, core material and fission product residue from the EBR-I Mark II core meltdown in November of 1955. The material was packaged in four containers, two 55-gallon drums and two cans fabricated from sections of pipe. The physical arrangement of the waste packages is shown in Figure 1, and the calculated isotopic curie values currently present in the containers is shown in Table I. Since the waste material contains plutonium, it cannot be processed with the slightly contaminated $\mathrm{NaK}$ from the EBR-I primary coolant system.

II . OBJECTIVE. The EBR-I Decontamination \& Decommissioning (D\&D) Program Plan recommended that the radioactively contaminated packages be removed from the EBR-I NaK storage pit and transported to a safe, temporary storage area. The objective of this activity was to accomplish the removal, transportation, and relocation of the waste packages in a manner which would not jeopardize the safety of personnel nor the quality of the environment.

III .TECHNICAL APPROACH. Planning for the activity included: conductance of a radiation survey of the $\mathrm{NaK}$ storage pit contents; performance of a radiation and chemical hazards evaluation; selection of a suitable interim storage area for the waste containers; development of a detailed operating procedure for the activity; fabrication of special tools and handling equipment; and performance of the activity with dummy packages. The actions were considered to be adequate to insure the safety of the planned activity.

IV. DISCUSSION. Cleanup operations at EBR-I (after the November, 1955 Mark II core meltdown), produced four containers of highly radioactive and plutonium contaminated waste. The waste containers, consisting of two 55-gallon Mine Safety Appliance Research (MSAR) drums and two cans fabricated from pipe sections, were blanketed with argon gas and placed in temporary storage in a below-grade pit approximately 100 feet west of EBR-I. The waste containers were equipped with pressure gages to show the cover gas pressure; however, over the period of 19 years, the gages may have become blocked by alkali metal oxides, and the inert cover gas may have leaked allowing the entrance of oxygen from the atmosphere. Thus the containers are suspected of containing the potassium superoxide $\left(\mathrm{KO}_{2}\right)$, potentially explosive when brought in sudden contact with NaK and/or organic materials. Movement of the waste constituted a hazard of uncertain dimensions, yet it would be necessary to move it in order to process the waste or transfer it from EBR-I to new interim storage.

The equipment designed for processing the lightly radioactively contaminated $\mathrm{NaK}$ (4,000 gallons in the EBR-I primary coolant drain tank) cannot be used to process the plutonium contaminated waste since the equipment is not compatible with the general design criteria for new plutonium facilities, Part II, Section H of AECM Appendix 6301. Lacking any other available facility at NRTS where the waste could be processed, the only option acceptable was movement of the waste to new interim storage at NRTS, pending provision of a facility where the waste could be processed safely. Based upon the above, planning for transfer of the waste containers from EBR-I was initiated. 


\section{TABLE I}

Isotopic Curie Values* Calculated

to be Present in the Contaminated NaK Packages

\section{Isotope}

Sr-90

Y-90

Zr-93

Tc-99

Ru-106

Rh-106

Sn-121m

Sb-125

Te-125

Cs-135

Cs-137

Ba-137m

Pm-147

Sm-151

Pu-239

Pu-240

Pu-241 $\underline{\text { Curie Value }}$

$8.25 \times 10^{1}$

$8.25 \times 10^{1}$

$4.21 \times 10^{-3}$

$1.74 \times 10^{-2}$

$1.09 \times 10^{-3}$

$1.09 \times 10^{-3}$

$7.40 \times 10^{-3}$

$6.06 \times 10^{-2}$

$1.67 \times 10^{-3}$

$1.92 \times 10^{-3}$

$8.30 \times 10^{1}$

$7.64 \times 10^{1}$

$6.84 \times 10^{0}$

$2.92 \times 10^{0}$

$6.12 \times 10^{-1}$

$1.19 \times 10^{-1}$

$3.53 \times 10^{0}$

*Only values greater than $10^{-3}$ curies are entered in the table.

Iodine isotopes of any radiological consequences have long since decayed away. The noble fission gas, $\mathrm{Kr}-85$, has not been entered since it would have evolved from the NaK shortly after the accident. 
1. Radiation Survey. The NaK storage pit was opened October 16, 1973 and a radiation survey was conducted. The results are shown in Figure 2, and form the basis for the design of the shielding and transport container.

2. Radiation Hazard Evaluation. The maximum radiation measured at contact with any of the waste packages was $7 \mathrm{R} / \mathrm{hr}$. Radiation calculations were performed which indicated that a steel box container and shielding provided by a one-foot thickness of dry sand would yield a radiation level at the steel box sides not exceeding $250 \mathrm{mR} / \mathrm{hr}$. Corresponding radiation level at the tractor driver compartment would be less than 40 $\mathrm{mR} / \mathrm{hr}$. Based on one hour travel time from EBR-I to the new storage area, dose rates to the driver would not exceed ANC's Administrative Exposure Guides.

Calculations were also performed to determine the impact of a $\mathrm{NaK}$ fire involving the entire pit inventory and which could not be extinguished. The analysis concluded that if the entire inventory of EBR-I contaminated $\mathrm{NaK}$ were consumed in an uncontrolled fire, doses to personnel at Central Facilities Area (CFA), Chemical Processing Plant (CPP) and Test Reactor Area (TRA) would be low whether the New Lung Model or the ICRP Report of Committee II Model were used for comparison.

Criticality calculations were not conducted since the maximum inventory of $\mathrm{Pu}$ postulated is due to the 10.5 grams of experimental specimens which were not recovered during disassembly of the Mark II core, and are therefore assumed to be in the four contaminated $\mathrm{NaK}$ packages. Since the maximum amount of fissile material in the packages is two orders of magnitude less than a critical mass, no criticality accidents could occur.

3. Chemical Hazards Evaluation. Due to concern that potassium superoxide $\left(\mathrm{KO}_{2}\right)$ may have formed in the NaK containers over the period of some 19 years since the $\mathrm{NaK}$ was encapsulated, and that a $\mathrm{NaK} / \mathrm{KO}_{2}$ mixture might be explosive under certain conditions of shock or sudden contact of the one compound with the other, an explosive hazards analysis and evaluation of $\mathrm{NaK}$ and $\mathrm{KO}_{2}$ was conducted, culminating with a series of tests by a subcontractor, Cook Associates, Inc., to determine and evaluate the explosive parameters of $\mathrm{NaK} / \mathrm{KO}_{2}$ mixtures. The investigation proved conclusively that: (1) liquid or solid $\mathrm{NaK} / \mathrm{KO}_{2}$ mixtures will not explode in "drop tests" or "impact tests"; (2) liquid $\mathrm{NaK} / \mathrm{KO}_{2}$ mixtures will self-ignite with the generation of heat but no gas generation; and (3) the $\mathrm{NaK} / \mathrm{KO}_{2}$ reaction does not fulfill either the high pressure or loud noise criterion for an explosion. It was concluded, therefore, that the handling or movement of the contaminated $\mathrm{NaK}$ containers would not result in gas generation or overpressures sufficient to cause container rupture.

4. Selection of Suitable Interim Storage Area. A number of excessed NRTS facilities, including several bunkers, were surveyed to determine suitability for temporary storage of the four waste packages. The criteria were: (1) isolation from public traffic, (2) security against accidental or purposeful entry, (3) protection from the environment, (4) ease of retrievability, and (5) low external radiation level. The ARVFS bunker, Figure 3, satisfied all the criteria and was available as excessed government property. The site was approved by AEC-ID for the temporary storage of the EBR-I waste packages and modifications were engineered to improve the entry resistance of the facility. 


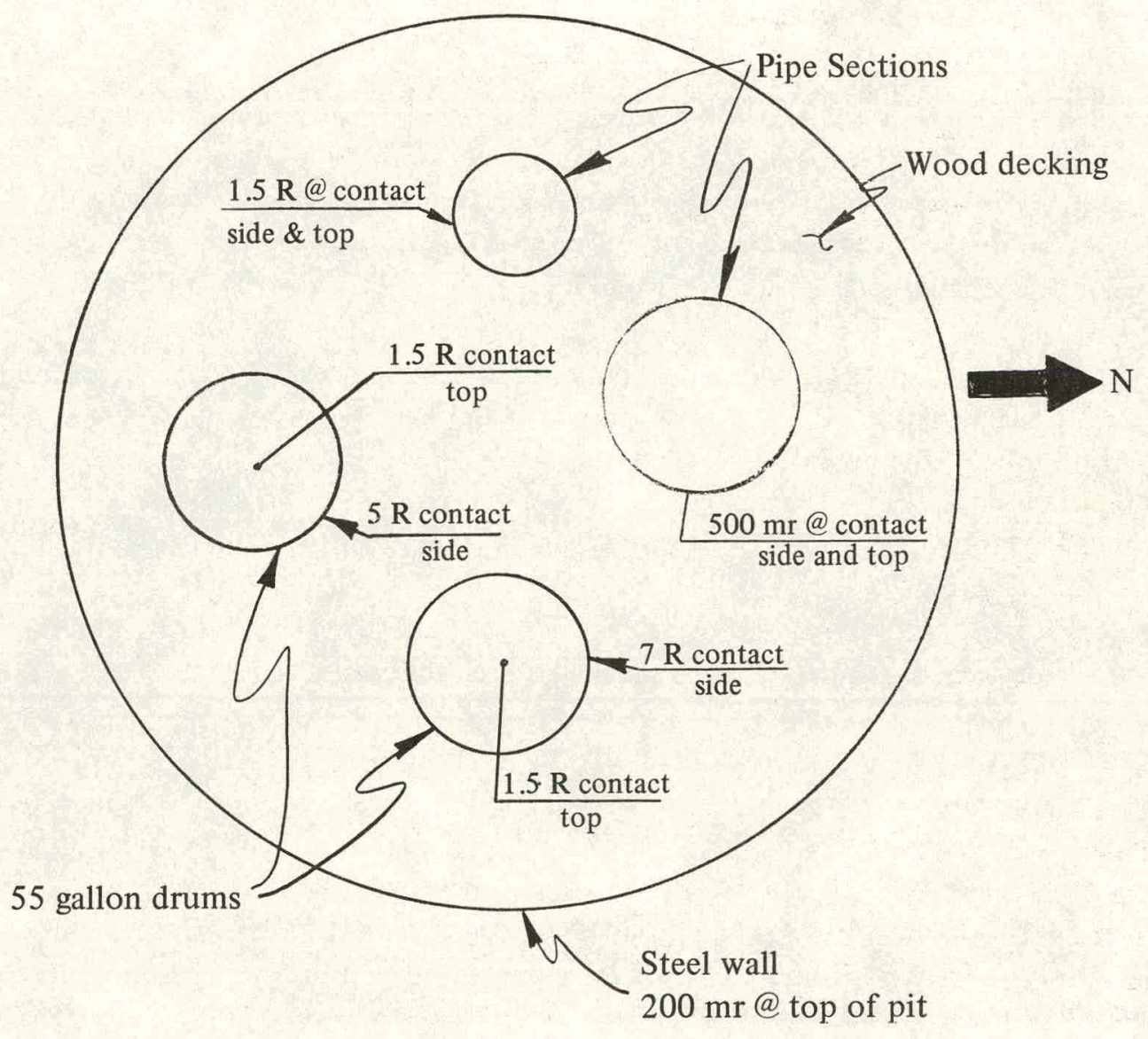

Fig. 2. NaK Storage Pit Radiation Survey. 


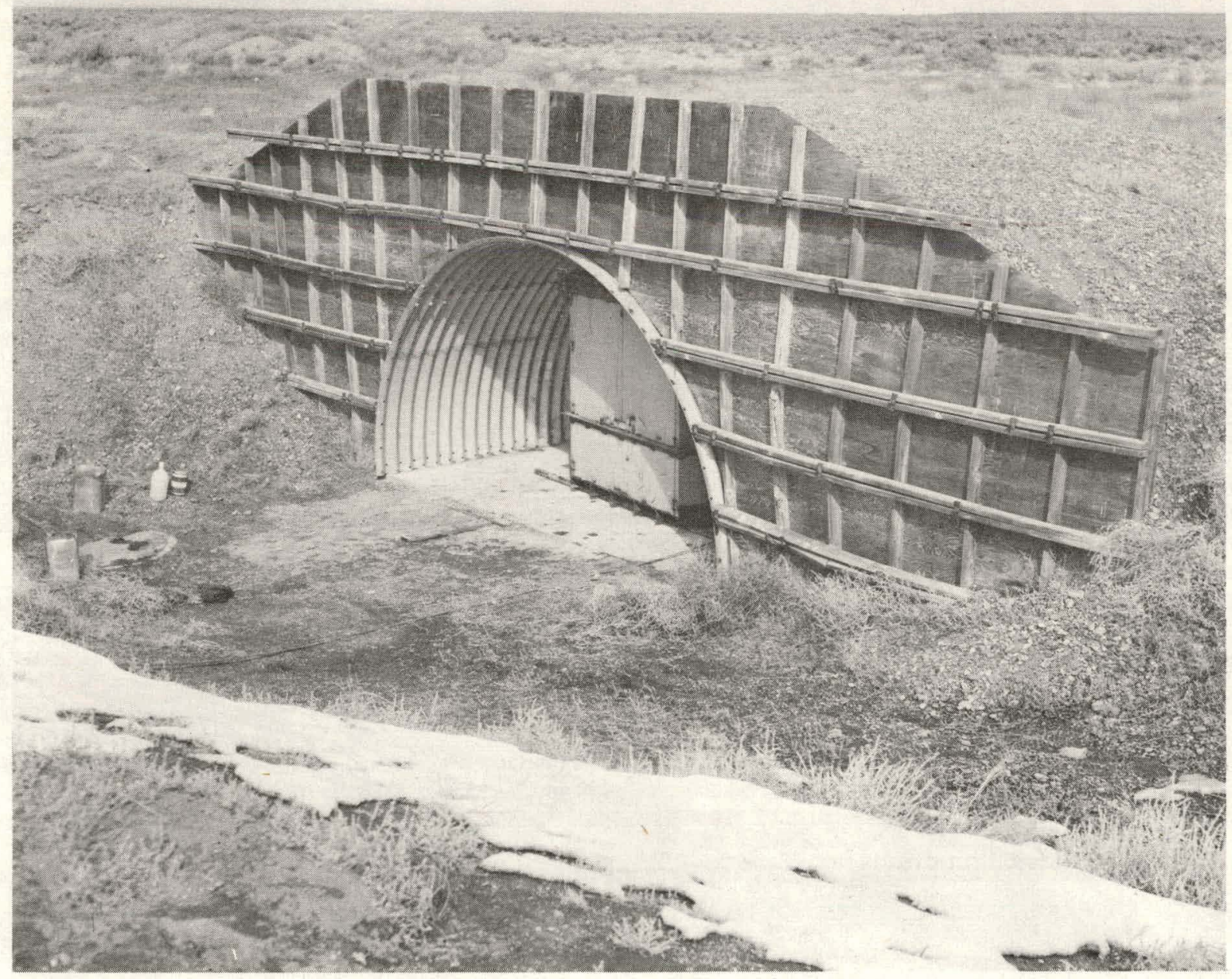

Fig. 3. Army Re-Entry Vehicle Facility Site (ARVFS) Bunker. 
5. Development of NaK Removal, Transportation and Restorage Procedure. A detailed procedure was developed for moving the two drums and two fabricated containers of radioactively contaminated $\mathrm{NaK}$ from the NaK Storage Pit at EBR-I to temporary storage at the ARVFS bunker. These items were to be handled remotely, using approved and demonstrated methods, to prevent exposure of personnel to potential chemical reaction and to radioactive material. The $\mathrm{NaK}$ containers were to be placed inside the steel box container, shielded by sand fill, and transported on a lowboy trailer, see Figure 4 . In the unlikely event of a container rupture or leakage of $\mathrm{NaK}$ from the container during the handling operations, personnel involved in the handling operations were to be protected by protective gear in accordance with the Alkali Metals Safety Handbook for EBR-I. Radio contact with WCC was to be provided by a security escort, who would have instructions concerning whom to contact in the event of an accident. The NaK containers would remain in the steel box container when placed in restorage at the ARVFS bunker.

\subsection{Prerequisites}

(1) Remove wood/transite partitions and lighting fixtures from ARVFS Bunker.

(2) Prefab closure panels for front of Bunker from $1 / 8$ in. steel sheet reinforced with 2 in. $x 2$ in. steel angle stiffeners and weld cable tray closure plate.

(3) Modify steel box container for top loading, and install lifting eyes.

(4) Additional equipment and/or personnel to be on hand:

a. Twenty-ton lowboy and tractor with tiedown rigging.

b. Four pieces 2 in. Sch. 40 pipe 8 -feet long for rolling container into bunker.

c. Twenty-five-ton mobile crane with 80 -foot boom.

d. Two special drum clamps with handling tool.

e. Dump truck with 10 cubic yards of dry sand and tailgate spout for loading sand hopper.

f. Ten-ton forklift for rolling dumpster container into bunker.

g. Portable welding outfit to tackweld steel over front of bunker.

h. Security escort for the transfer from EBR-I to the ARVFS Bunker.

i. Fire Department escort. 


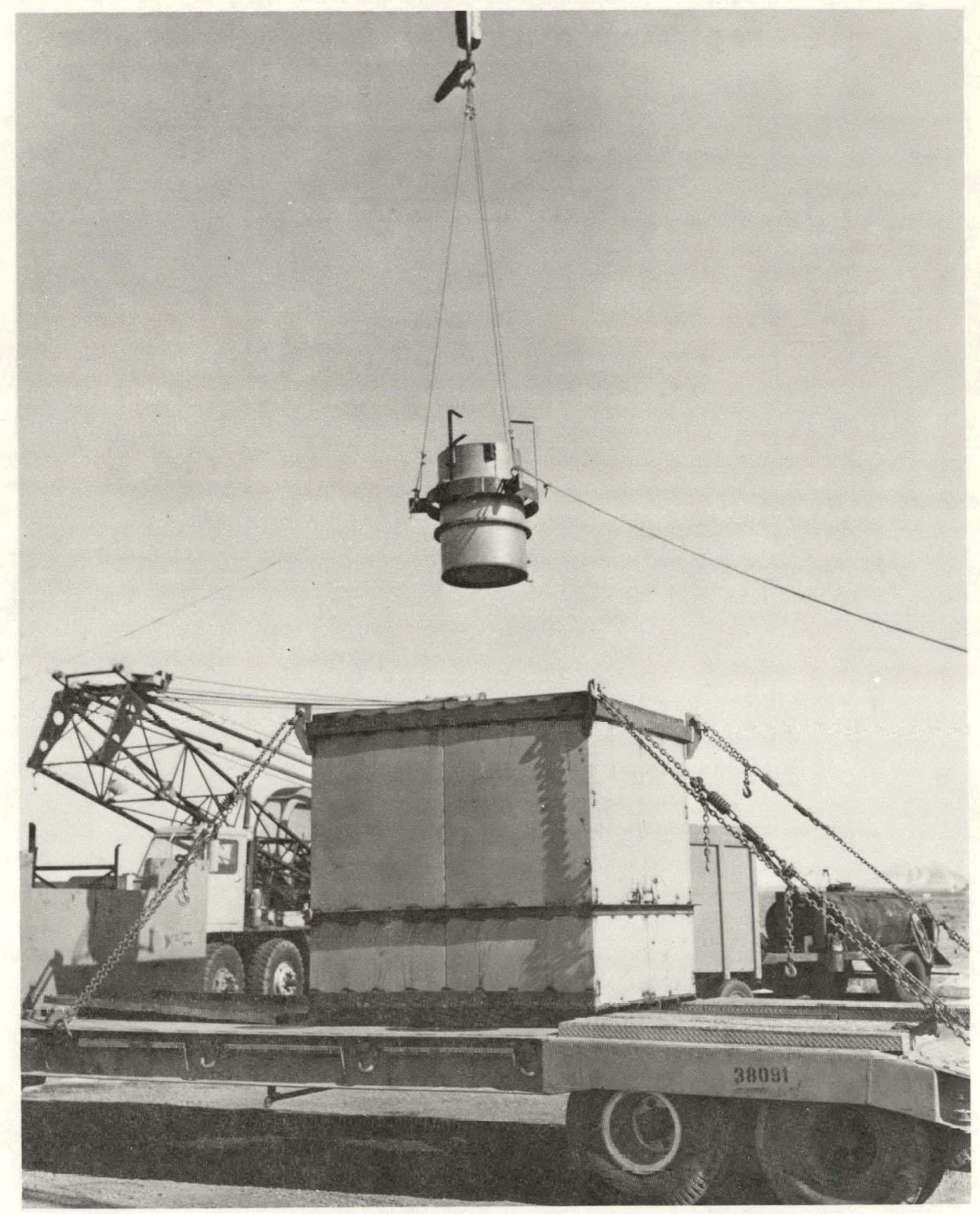

Fig. 4. NaK Drum Transfer Operation. 
j. Protective clothing per ANC Alkali Metals Safety for EBR-I.

k. Temperature indicators $\left(\right.$ Tempilstick $\left.^{\circ}\right)$ rated at $200^{\circ} \mathrm{F}$, and reach rod.

1. Constant air monitor.

m. HP personnel with radiation monitoring equipment.

n. Mirror for indirect observation of the NaK pit contents.

\subsection{Procedure}

A Health Physicist (HP) with radiation monitoring equipment will be present at all phases of this operation, and a fire department escort will be required during the removal and transfer operations.

\section{(1) Loading at EBR-I}

Check equipment requirements and have the needed items ready at the work location.

(2) Remove lid from the NaK disposal pit with the 25-ton crane.

(3) Mark container sides and top with tempilstik ${ }^{\mathrm{O}}\left(200^{\circ} \mathrm{F}\right)$ using a reach rod to avoid personnel entry into the pit.

(4) Using reach rod, affix the drum clamp to the NaK drums and lifting hook through the vessel lifting eyes. Use two tag lines to control swinging during the lift.

(5) Using the 25-ton crane, shake the containers individually and observe the tempilstik ${ }^{\mathrm{O}}$ marking for change of temperature. Use a mirror to avoid direct line of sight into pit.

(6) If tempilstik ${ }^{\mathrm{O}}$ does not indicate $200^{\circ} \mathrm{F}$, wait 30 minutes and continue with procedure, steps 8 through 13 .

(7) If tempilstik ${ }^{\mathrm{O}}$ indicates a temperature rise to greater than $200^{\circ} \mathrm{F}$, delay operations until the container skin temperature drops to below $200^{\circ} \mathrm{F}$ as evidenced by use of the tempilstik ${ }^{\mathrm{O}}$.

(8) The steel box container will be located and tied down on the rear of the lowboy deck. Lift drums one at a time with 25 -ton crane and place in container leaving clamps and rigging in place on the drums. Tie the drum 
rigging to keep the individual drum lifting cables together. Then lift vessels by placing lifting hooks in through the vessel lifting eyes with a handling tool. Lift and place vessels in container.

(9) Place dry sand in container using crane and hopper. Sand level to be about twelve inches over tops of drums and vessels. (Verify tag lines are attached.)

(10) Proceed to ARVFS Bunker with container mounted on lowboy, travel time approximately one hour.

NOTE 1: The calculated radiation level at contact with the surface of the container will be $250 \mathrm{mR} / \mathrm{hr}$. The radiation level at the driver's compartment (excluding lead shielding) will not exceed $40 \mathrm{mR} / \mathrm{hr}$. If two inches of lead shielding is used, the driver's compartment would see less than $1 \mathrm{mR} / \mathrm{hr}$.

NOTE 2: Do not exceed $15 \mathrm{mph}$ enroute to ARVFS Bunker.

(11) Attach rigging and lower the loaded container with 25-ton crane to rest on pipe rollers at front of bunker.

(12) Pull container into bunker using cable sheave arrangement and leave pipe rollers under container for ease of removal at a later date.

(13) Place steel sheets at front of bunker using crane and tackweld sheets and angles in place.

(14) Verify dike has been repaired prior to leaving the area.

\subsection{Rehearsal}

This procedure will be rehearsed and witnessed by a cognizant safety representative.

(1) The simulated loading will be performed at the $\mathrm{CF}$ equipment yard instead of EBR-I.

(2) A dummy drum filled with sand will be substituted.

(3) Welding of the bunker cover plates will not be rehearsed. 
V. OPERATIONS. The operations performed in the removal, transportation, and restorage of the contaminated $\mathrm{NaK}$ packages were done in accordance with the procedure detailed in Section IV of this report.

1. Rehearsal. All personnel and equipment required to perform the operations were assembled February 27, 1974 at the CFA equipment yard, and a complete rehearsal of all operations was performed.

2. Activity Accomplished. The EBR-I NaK Storage Pit was opened at 1505 hours April 4, 1974 and hi-volume air samplers were started. The AEC-ID approved procedure was followed exactly. Shaking the NaK packages produced no evidence of exotherms and at 1640 hours, transfer of the packages to the steel box container on board the lowboy was initiated. By 1725 hours all the packages were in the steel box container and placement of sand was initiated. $\Lambda$ fter placement of the sand, the body field in the tracker cab was 0.4 $\mathrm{mR} / \mathrm{hr}$. The NaK Pit surveyed at less than $0.2 \mathrm{mR} / \mathrm{hr}$ at the floor level. The tracker and lowboy arrived at the ARVFS bunker at 1935 hours and the restorage operation was concluded at 2015 hours. See Figure 5 for the appearance of the steel box container in the bunker, and Figure 6 for the appearance of the bunker with the closure plate installed. The radiation level at contact with the closure plate was less than $3 \mathrm{mR} / \mathrm{hr}$.

VI. CONCLUSIONS. Conclusions reached as a result of the activity were: that the contaminated $\mathrm{NaK}$ packages were still intact after 19 years of storage at the EBR-I NaK Storage Pit; that only minor amounts of $\mathrm{KO}_{2}$ could have been present in the packages since no exotherm was experienced during the shaking of the drum; that radioactively contaminated $\mathrm{NaK}$ had not leaked from the packages since the pit floor radiation field was less than $0.2 \mathrm{mR} / \mathrm{hr}$; that the $\mathrm{NaK}$ pit could be demolished with no additional decontamination required; and that the NaK storage conditions at ARVFS are equal to or superior to those at the NaK Storage Pit. The four contaminated NaK waste packages have been removed from the EBR-I Complex and safely placed in interim storage until adequate equipment for processing the material becomes available.

\section{REFERENCES}

1. An Explosive Hazards Analysis and evaluation of the Eutectic Solution of Sodium and Potassium $(\mathrm{NaK})$ and Potassium Superoxide $\left(\mathrm{KO}_{2}\right)$, Subcontract No. S-1306. 


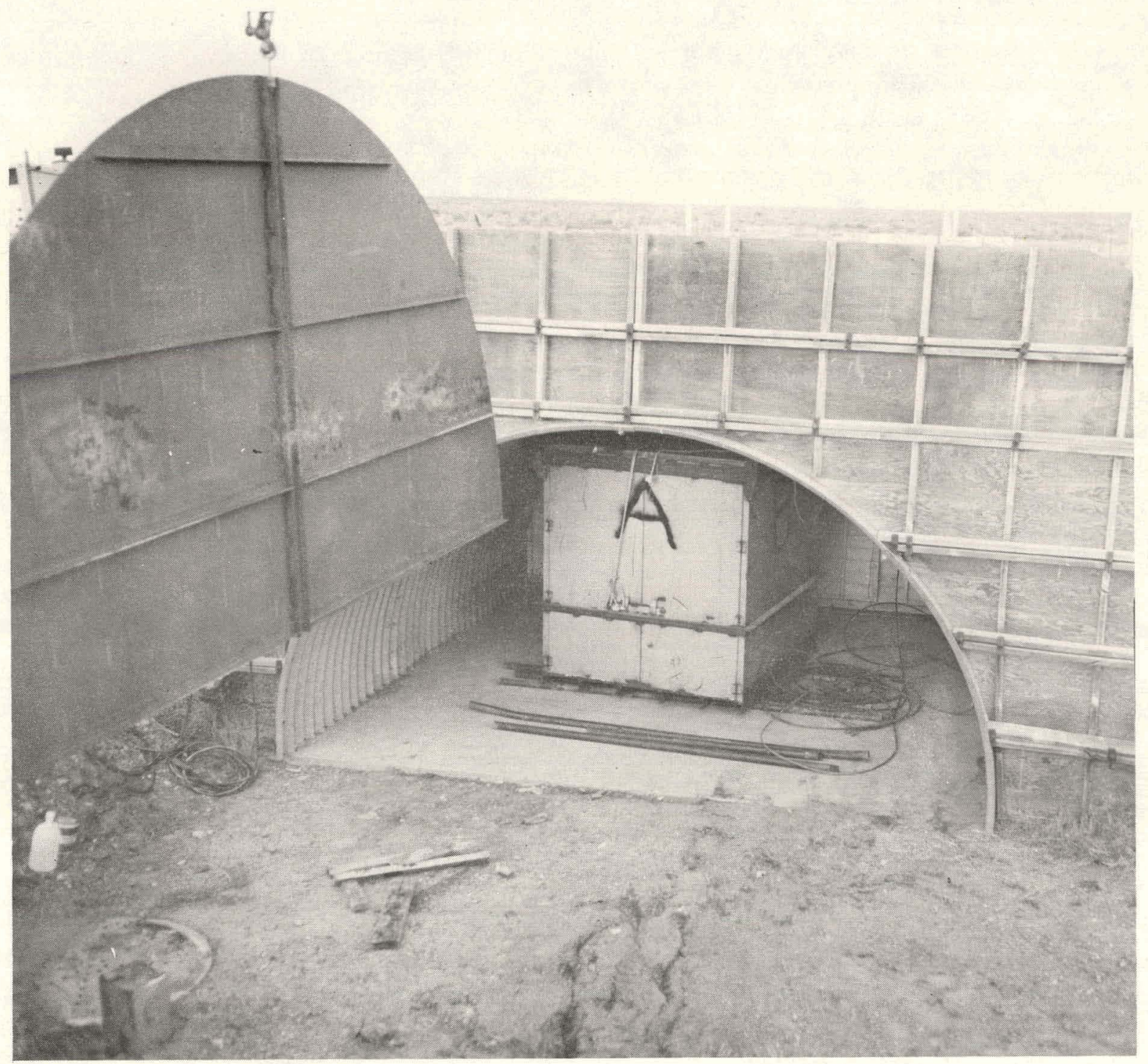

Fig. 5. Steel box container in ARVFS. 


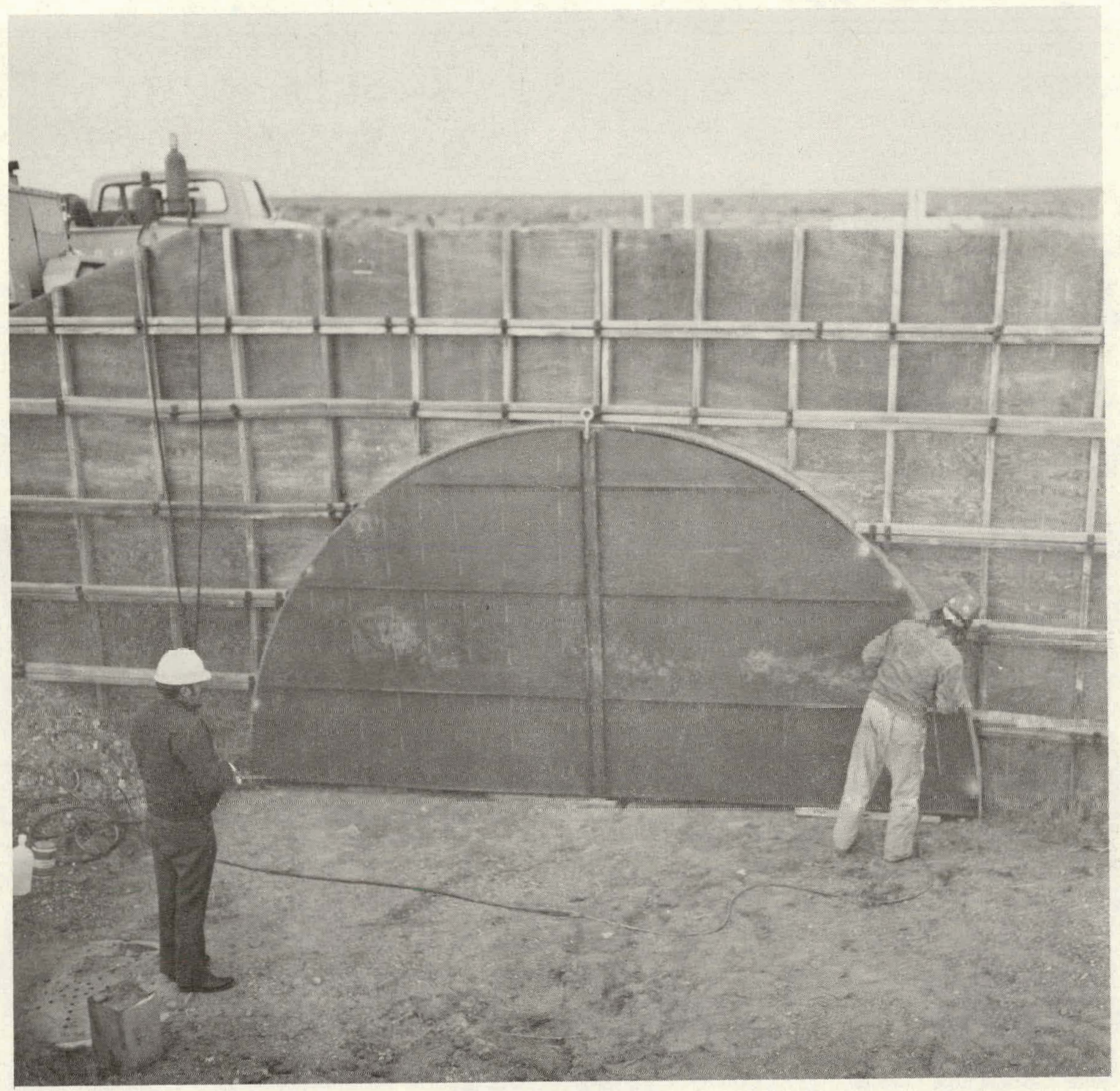

Fig. 6. ARVFS Closure Plate 
